\title{
Material lives of the poor and their strategic use of the workhouse during the final decades of the English old poor law
}

\author{
JOSEPH HARLEY*
}

ABSTRACT. This article is the first to use a combination of three different types of inventories from Dorset to examine the material lives of paupers inside and outside Beaminster workhouse. It argues that life was materially better for paupers on outdoor relief, compared with workhouse inmates and with paupers in the moments before they entered the workhouse. The article also examines how the poor used admission into the workhouse as part of their economy of makeshifts. The evidence demonstrates that the able-bodied poor used the workhouse as a short-term survival strategy, whereas more vulnerable inmates struggled to use this tactic. This article therefore furthers our understanding of the nature of poor relief and adds further weight to recent historical work that has emphasised pauper agency.

\section{INTRODUCTION}

By the 1830s public opinion had turned against the way in which workhouses were managed. ${ }^{1}$ On one side, people viewed workhouses as the location of misery and injustice due to overcrowding, poor management and their prisonlike character; others conversely viewed workhouses as institutions which made the poor idle and immoral, owing to the lack of discipline and the relative material abundance found within the workhouse. ${ }^{2}$ A Royal Commission was set up in 1832 to investigate the state of the poor laws. It concluded that many workhouses were places of 'great mal-administration' which contributed to the idle, ignorant and immoral state of the able-bodied poor. A major contributor to this was the belief that workhouses were too comfortable and kind to inmates. One carefully selected workhouse master observed that 'It

\footnotetext{
* University of Leicester.
} 
is a common remark among our paupers that they live better in the house than they ever lived before', on account of 'the goodness of the beds and bedding, and the wholesomeness and quantity of the food' ${ }^{3}$ The subsequent Poor Law Amendment Act of 1834 was based in part on these arguments and aimed to reshape workhouses to make them less comfortable than the homes of the independent poor and deter people from seeking relief.

Historians have written extensively about the build up to the new poor law and contemporary feelings about the apparent kindness inmates received in workhouses ${ }^{4}$ yet surprisingly little empirical work has assessed the extent to which these views reflected reality. Most of our knowledge of the material contents of the workhouse is based on simple descriptions of occasional workhouse inventories. In Ethel Hampson's influential book on poverty in Cambridgeshire, for instance, she merely quoted some of the most notable items found in the rooms of a few scattered examples of workhouse inventories. More recently, Samantha Williams simply went from room to room and described the beds and the contents of the pantry recorded in a workhouse inventory from Bedfordshire. ${ }^{5}$ Examples like these demonstrate repeated missed opportunities to understand workhouse material life beyond a rudimentary level and to understand what inmates' lives were actually like. By relating these workhouse inventories to wider sources, such as workhouse rules, overseers' and workhouse accounts, workhouse dietaries and admission registers, it is possible to go beyond a simple descriptive inventory and develop a much more nuanced understanding of who used the beds in the workhouse, how people were fed, and how the parish attempted to maintain discipline, for example. Recent work has started to use workhouse inventories in greater detail. Susannah Ottaway and Alannah Tomkins both argued that eighteenthcentury workhouse material surroundings were generally adequate for inmates and that they were well fed. ${ }^{6}$ Ottaway even argued that workhouses were furnished 'at a standard of living roughly equivalent to that of the laboring poor outside of the house'. ${ }^{7}$ There is, however, very little published research that analyses the material environment of the workhouse during the 'crisis' years of the late eighteenth and early nineteenth centuries, when the costs of funding poor relief rapidly rose and when calls for a harsher workhouse test reached a peak. ${ }^{8}$

Insufficient attention has also been given to an important but different group of inventories, which were taken of inmates' belongings at the moment that they entered the workhouse. These inventories were either made to catalogue the goods that a pauper had been allowed by the parish to keep in temporary storage whilst they were dwelling in the workhouse (storage inventories), or were used to record which goods the parish had taken and kept in exchange for indoor relief (inventories of goods taken from inmates). Understandably, both of these types of inventories have rarely been used by historians as it 
is often difficult to find a large enough sample, despite the fact that it is not uncommon for parish sources to mention that it was their policy to seize or store inmates' possessions. ${ }^{9}$ Both Francis Hill and Susannah Ottaway were able to find several inventories of inmates from Lincolnshire and Essex, respectively, but although they were able to demonstrate that people's material circumstances were bleak at the moment that they entered the workhouse, both their analyses were very brief and only described the items found in the inventories. Hill also neglected to contextualise the inventories by not assessing the inmates' demographic backgrounds and the length of time that the inmates were in the workhouse. ${ }^{10}$ Though rare, these examples demonstrate that inventories of inmates do survive and have unexplored potential to reveal the material world of paupers at the moment that they entered the workhouse. Moreover, through the use of pauper inventories in conjunction with inventories of inmates, the indoor poor can be compared with the wider pauper population on outdoor relief, allowing us to develop a deeper understanding of how material wealth varied among the poorest in society. ${ }^{11}$

The majority of research on workhouse inmates has tended to examine the most vulnerable, such as the elderly, sick, single mothers and children, ${ }^{12}$ and there is now a sizable literature on the economy of makeshifts, pauper agency and how the poor could use the workhouse strategically. ${ }^{13}$ However, very little attention has been given to the able-bodied within this literature, especially beyond London and during the final decades of the old poor law. Most research on the able-bodied poor has tended to examine those on outdoor relief and those involved in schemes such as Speenhamland, meaning that some writers have been quick to dismiss the group in regards to indoor relief. Geoffrey Oxley, for instance, argued that 'Able-bodied males rarely found their way into the workhouse' as the house 'offered no solution since, as a rule, such poverty was temporary whether caused by unemployment between jobs, sickness, or worklessness following a downward turn in the trade cycle'. As a result Oxley claimed that it was seen as 'counter-productive' to put the able-bodied in the workhouse, only to have them leave a short time later when work reappeared and struggle to set up a new home. ${ }^{14}$ Indeed, parishes generally preferred to relieve able-bodied parishioners away from the workhouse. However, the contemporary debate that surrounded the group clearly suggests that they provoked anxiety and created a strain on resources, despite their relatively small numbers. They consequently warrant analysis in their own right.

Through the use of the case study of Beaminster workhouse in Dorset, this paper addresses these gaps in the literature and these unexplored methodological avenues of research. After introducing the reader to the case study and the excellent range of inventories that survive for the parish, the demographic make-up of the workhouse is examined. It is argued that the majority of 
workhouse inmates were the elderly and young, but over the period more ablebodied parishioners and their families used the workhouse for temporary periods until their problems had subsided and they were ready to leave. Next, through the innovative comparison of three different types of inventories, the findings demonstrate that paupers who stayed in their own home on outdoor relief generally owned a greater quantity and variety of goods than those who turned to the workhouse. Workhouse material life on the other hand was generally adequate, but was not as materially abundant or overly comfortable an environment as some contemporaries feared. The article ends by reconstituting the lives of individual inmates from the workhouse. It finds that the able-bodied poor generally used the workhouse as a short-term survival strategy and subsequently left when they could. Single or widowed parishioners also tried to use the workhouse as a short-term measure, but found it more difficult to re-establish their independence outside the workhouse.

\section{BEAMINSTER}

Beaminster is a market town located in the west of Dorset. Its population in 1775 was 1,955 and by 1831 had increased to 2,968. Approximately one-fifth of the male population was employed in agriculture in 1831, while the remainder were employed in industries that were largely in transition. In the late eighteenth century the majority of the population was employed in industries such as sail-cloth weaving and cloth manufacture from local wool. However, by the 1830s the wool industry had become 'of little importance to the place' and the sail-cloth industry had started to decline, making it increasingly difficult for weavers to earn a living. ${ }^{15}$ Population growth, notoriously low real wages and fewer earning opportunities for women and children also perpetuated these problems. The town was, however, well supplied with a range of shops and services. This allowed a variety of other industries to appear such as pottery works, tanning and metalworking, but these were never able to fill the void that weaving had left. ${ }^{16}$

\section{SOURCES}

The rare array of sources that survive from Beaminster affords the historian scope to assess the town's workhouse from a number of angles. The first type of inventories consists of those that were made of inmates' possessions at the point that they entered the workhouse. Beaminster's records contain 23 of these inventories dated between 1817 and $1832 .{ }^{17}$ These 23 inventories were made to catalogue the items that new inmates brought into the workhouse with them, which were subsequently stored by the parish (storage inventories). 
Then, if and when they left the workhouse, the items were ticked off and returned to the pauper. The temporary storage of goods in Beaminster workhouse was generally reserved for able-bodied parishioners with families, and a small number of single or widowed inhabitants. ${ }^{18}$ Using the workhouse in this way acted as an important safety-net which people could use during temporary difficulties and demonstrates that indoor relief could be tailored to help paupers. Unfortunately, it is unclear if the goods were stored in the workhouse or elsewhere. Other areas had a similar policy, such as Lincoln and St Martin-in-the-Fields in London. ${ }^{19}$ In Chelmsford, Essex in the early eighteenth century, the policy of storing inmates' belongings was particularly used by people during temporary periods of sickness. ${ }^{20}$ Sometimes the items catalogued for storage would be retained by the parish when the officials realised that the inmate would not be able to support themselves outside the workhouse. ${ }^{21}$ When this happened, the items were at some point either sold, kept for use in the workhouse or given back to the pauper's family, at the parish's discretion.

In other workhouses, inmates' possessions were either taken to be sold or used to furnish the workhouse as soon as the inmate entered (inventories of goods taken from inmates). Several places in Dorset applied this policy. In early nineteenth-century Stour Provost, for instance, it was ordered that the workhouse Master should take "what Goods they [inmates] bring when Admitted, and take care that it be cleaned for the Use of the House'. ${ }^{22}$ In St Albans, Hertfordshire, the consequence of this policy was 'that there has been no Occasion to buy more than three Beds, and a few other Things' for the workhouse during the $1720 \mathrm{~s}^{23}$ In Wimbledon, Surrey, the taking of goods became a prerequisite of entering the workhouse; ${ }^{24}$ while in Leeds, paupers were declined outdoor relief if they refused to accept an order to enter the workhouse where they would subsequently have their possessions taken. ${ }^{25}$ Consequently, these policies left the pauper in a very difficult situation regarding whether to accept indoor relief when they knew that their possessions would be taken. The parishioners who entered the workhouse under these conditions must have been very desperate. Naturally, this policy made inmates more materially destitute so it is likely that it was generally applied to longterm residents such as the old, who the parish thought were less likely to regain their independence. ${ }^{26}$ If they did leave the workhouse then the parish often had to give them a number of basic household goods to set up a new home.

There are potential problems for the historian as a result of these differing policies. If the parish decided to keep the goods or use them in the workhouse, then it was in the pauper's best interests to have a friend or relative look after their possessions or sell them before they entered, ${ }^{27}$ whereas if the goods were stored by the parish and not subsequently kept by the parish then this strategy was not necessarily needed. Thus, although these two types of inventories of 
inmates are seemingly very similar, these subtle differences demonstrate that storage inventories are probably a better marker of pauper material wealth before they entered the workhouse than those that record the loss of inmates' goods. The results from any set of storage inventories should nevertheless be treated with caution, as this arrangement all hinged upon trust that both parties would uphold their end of the bargain. Understandably, some paupers distrusted workhouses and saw them as prisons where they lost their independence and where they were mistreated. ${ }^{28}$ However, other workhouses took a more pragmatic view on how to treat inmates and how to apply policies. Inmates could use this to their advantage. In Dartford, Kent, for instance, Mrs String had her goods taken upon entry to the workhouse but was able to negotiate and use her own bed in the workhouse. ${ }^{29}$ Beaminster appears to be one of these more pragmatic workhouses. The storage inventories from Beaminster survive over a period of 15 years and some inmates even used the workhouse more than once and had more than one storage inventory made of their possessions. This suggests that paupers used and trusted the system and suggests that the parish actively helped paupers in this manner. This agreement was essentially one built on self-interest - officials were most interested in preventing the pauper from becoming a long-term dependant of the parish; and the pauper accepted this help as he/she needed it and because it suited them at that moment in time.

In order to contextualise Beaminster's storage inventories, 22 pauper inventories from Dorset dated between 1770 and 1822 are used to uncover the material wealth of paupers on outdoor relief. ${ }^{30}$ By comparing these two types of inventories, the extent to which people were impoverished before they entered the workhouse and the extent to which the workhouse was materially rich can be examined. Pauper inventories are a complex source and, like the inventories of inmates, have rarely been studied by historians. ${ }^{31}$ Briefly, these particular inventories from Dorset tended to be made of the belongings of older parishioners and those who were more vulnerable to poverty, such as women and the widowed, and particularly people who had received a pension from the parish for an extended period of time. They were made to record the possessions somebody had at one point in time, with the aim of later taking the goods for the parish's benefit when they died.

The final category of inventories details the material contents of the workhouse (workhouse inventories). They can vary in quality but for Beaminster four very detailed workhouse inventories survive, dated 1785, 1822, 1827 and 1830. There are also two dated 1796 and 1818 which will be used infrequently as they are shorter and lack the detail of the others. ${ }^{32}$ Surviving workhouse rules demonstrate that workhouse inventories were predominantly made to protect parish goods from damage and theft. Beaminster's rules from 1834 ordered that inventories be made 'to observe the strictest economy and 
prevent to the utmost of their power any waste[,] spoil or damage being committed'. ${ }^{33}$ Some areas made workhouse inventories yearly and duplicates were distributed to officers to further protect the goods. In Wimbledon, Surrey, one inventory went to the overseer and the other went to the poorhouse mistress. ${ }^{34}$ Some parishes would even brand the goods to clearly demonstrate that they belonged to the workhouse. ${ }^{35}$ If inmates or pawnbrokers were caught handling stolen branded workhouse goods, they could be fined or imprisoned. ${ }^{36}$ Because workhouse inventories were primarily made to protect goods and were enshrined into workhouse rules, it is likely that they are some of the most complete and detailed inventories available to poor law historians. There is of course the potential for parts to be forgotten or missed by the appraiser. However, through the use of multiple inventories from one workhouse, additional information on particular rooms and items can be revealed and any discrepancies can be checked.

\section{BEAMINSTER WORKHOUSE AND ITS INMATES}

The use of institutional relief in Beaminster dates back to 1626 when $£ 300$ were bequeathed to house the poor. ${ }^{37}$ By the eighteenth century this institution had developed into a parish workhouse. From 1746 the parish employed paid officials to run the workhouse day-to-day and also employed surgeons to treat paupers inside and outside the workhouse. By 1810 the parish also appointed a 'Special Overseer' to directly manage the workhouse due to its 'excessive' spending. From 1760 the parish relieved all of its parishioners who sought relief in the workhouse. The only outdoor relief went to the sick, who were allowed a maximum of 1 shilling a week for no longer than a month. As time passed, this policy became more lenient and exceptions were increasingly made, which eventually led to it being abandoned by 1795 when bread prices became very high and the vestry had decided to subsidise its costs. ${ }^{38}$ Though inventories from the 1770s are assessed in this study, the main focus, however, is after 1795 when the parish used both indoor and outdoor relief and when the costs of poor relief increased significantly.

In 1776 most English workhouses could accommodate around 20-50 people. The smallest had a capacity of two people and the largest 500 people. ${ }^{39}$ Beaminster workhouse had a capacity of approximately 100 people after it was rebuilt in $1766 . .^{40}$ The total number of people that used the workhouse could fluctuate significantly each year. After 1795 when Beaminster reverted back to a combination of indoor and outdoor relief, there were on average 111 people in the workhouse at any one time between July 1796 and April 1798.41 By 1815 Beaminster roughly relieved two-fifths of its paupers in the workhouse, but the total number of inmates had dropped to around half of what it was in the $1790 \mathrm{~s} .{ }^{42}$ From 1810 Beaminster's 'Special Overseer' 


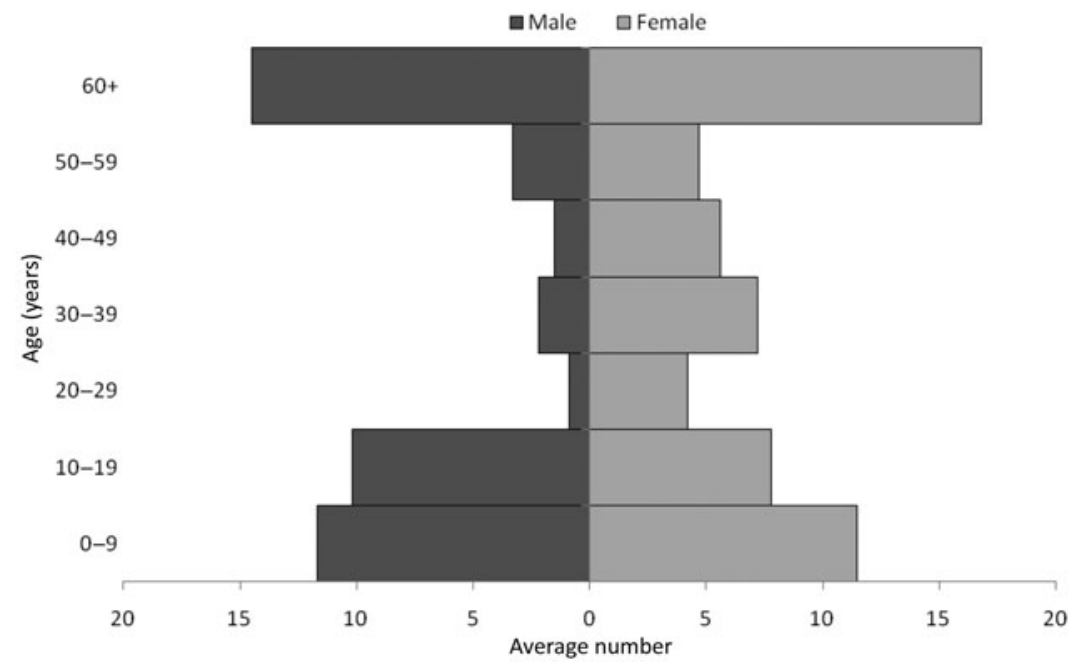

FIGURE 1. Gender ratios of inmates in Beaminster workhouse, sampled every two years, 1810-1834. Source: Dorset History Centre PE-BE/OV/7/4-5.

recorded the movements of individuals who moved in and out of the workhouse and also recorded their age. ${ }^{43}$ By sampling this source every two years I have constructed Figure 1, which records the demographic make-up of the workhouse. It demonstrates that the workhouse predominantly relieved Beaminster's most vulnerable parishioners: the old and young. Moreover, most of the young were pre-adolescent and most of the inmates aged over 60 years old were in fact aged over 70 or 80 years old. Most of the children were in the workhouse with their siblings and one or both of their parents, who were typically aged in their 30 s to $50 \mathrm{~s} .{ }^{44}$ Women outnumbered men by approximately two to one. This trend is broadly visible across the majority of other workhouses in the south and east, generally stemming from the increased infirmity, sickness and curtailed earning power that accompanied old age, whilst many of the young were in the workhouse because one or more of their parents were. Some were also orphaned, awaiting apprenticeships or born illegitimate. ${ }^{45}$

Figure 2 plots the total number of inmates in the workhouse each year at one moment. ${ }^{46}$ Between 1810 and the start of 1816 there were between 47 and 58 people living in the workhouse; however, from 1816 there was a significant increase in the total population, eventually reaching a peak of 118 inmates in 1822. It was not until around 1826 that the figures levelled off, but even then the numbers remained high compared with the years 1810 to 1815 and were still susceptible to rises and falls. 




FigURE 2. Total number of inmates in Beaminster workhouse at one moment, sampled every years, 1810-1834. Source: Dorset History Centre PE-BE/OV/7/4-5.

The rise in workhouse relief from 1816 to 1822 was probably influenced by wider economic factors, as well as parish policy. The year 1815 marked peace with France but also the start of a severe depression, in which most of the labouring poor received diminishing real wages and struggled to find work. ${ }^{47}$ It is likely that the local sail-cloth weaving industry particularly struggled after this period as there would have been less demand from the navy. Figure 3 corroborates these assumptions, by showing that all categories of inmates increasingly used the workhouse from $1816 .{ }^{48}$ Women remained the largest group throughout the period; however, adult men also increasingly used the workhouse following an increase of around 27 per cent in their numbers by 1834 . Moreover, during some years this increase was much greater, such as between 1816 and 1822 . The elderly of both genders increased in number over the entire period, but 1816 to 1822 again marked the biggest increase. Elderly women were more common than elderly men most years.

Most significantly, children and adolescents showed the greatest increase, tripling from 21 people in 1816 to 63 in 1822 . This rise mostly derives from the increase in people aged between 20 and 59 years old who brought their children into the workhouse with them. These included single or widowed mothers who used the workhouse indefinitely, and others who used the workhouse for short periods of time to give birth. Interestingly, there was a notable increase in the number of able-bodied couples with children 


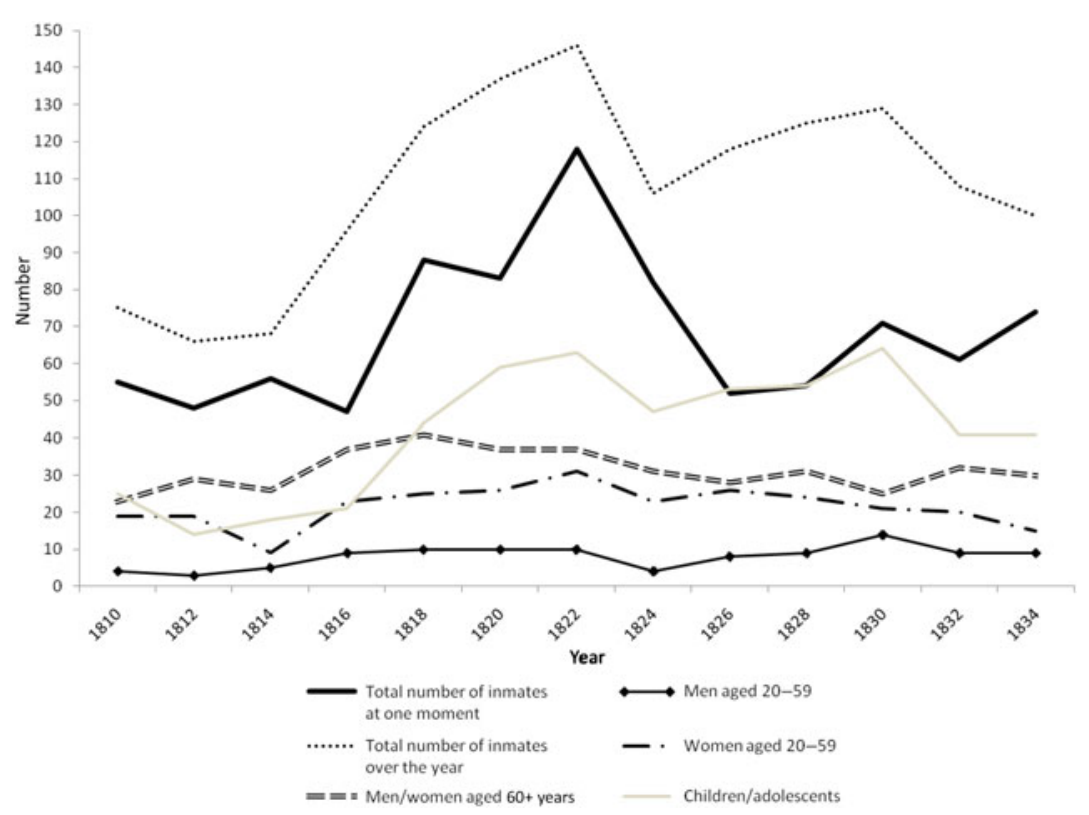

FIGURE 3. Gender- and age-related profile of inmates in Beaminster workhouse, sampled every two years, 1810-1834. Source: Dorset History Centre PE-BE/OV/7/4-5.

who entered the workhouse. The number of middle-aged men more than doubled between 1810 and 1822 and generally remained at this level in subsequent years. Women increased by 38 per cent between the same dates but their number gradually fell after peaking in 1822. On average these married couples each brought four children with them. Thus, despite the able-bodied appearing to be a seemingly insignificant group, they along with their families presented a significant challenge to the parish and its resources.

Figure 3 also plots the total number of inmates in the workhouse at one moment in time and the total number of people who used the house over the course of the year. Both lines follow relatively closely together between 1810 and 1824; however, in subsequent years the gap broadens. This demonstrates that there was a greater turnover of inmates, brought on by people using the workhouse for shorter periods of time. Most of these people were middle-aged married couples with large families, but less often single or widowed people (often with children) also used the workhouse in this way. These groups are explored further below in sections 7 and 8 , but these results strongly suggest that the workhouse had become an important part of some people's makeshift economy and an important refuge which could be used for a temporary period. Historians have commonly acknowledged that entering 
the workhouse was not always a permanent switch and that some people left the workhouse after only a short period of time. However, relatively little was known about the type of inmate who did this and how such practices were viewed by the parish beyond London and especially during the final decades of the old poor law. ${ }^{49}$ The results from Beaminster demonstrate that the ablebodied and their families particularly used the workhouse in this way. Moreover, the parish acknowledged the temporary nature of poverty that faced these paupers and allowed them to store their possessions whilst they stayed in the workhouse. These paupers would have caused a significant strain on parish resources, but the strain would have been temporary and would have helped to prevent most of these able-bodied paupers and their families from becoming long-term recipients of relief.

\section{PAUPER MATERIAL LIFE OUTSIDE THE WORKHOUSE}

Research on the household material wealth of the middle and upper classes has demonstrated that there was a significant increase in their ownership of fashionable and more luxurious goods over the eighteenth century and beyond. ${ }^{50}$ Equally, studies on the poor have demonstrated that they could also own a wide variety of household goods and clothing, especially by the later eighteenth century. ${ }^{51}$ Yet, despite this, research on the material lives of the poor is relatively sparse especially beyond London and the Home Counties. Some studies are even open to criticism, meaning that our overall knowledge of the group is very limited. Both Craig Muldrew and Ken Sneath, for instance, used probate inventories to assess the material world of the labouring population; ${ }^{52}$ however, the extent to which the labourers found within probate inventories are typical of the wider labouring population has often been questioned. ${ }^{53}$ Adrian Green recently attempted to use pauper inventories from Norfolk to assess the homes of the poor. His sample, however, included many unverified pauper inventories which were not checked against wider parish sources in order to determine whose possessions were inventoried and why. As a result, the sample was inclusive of wealthier members of society and people who did not receive any relief from the parish. ${ }^{54}$

This section takes an important step towards addressing this gap by analysing 23 storage inventories from Beaminster workhouse and 22 pauper inventories from Dorset, in order to uncover how impoverished people were at the point of entry to the workhouse compared with the wider outdoor pauper population. Despite Beaminster workhouse offering storage to inmates, it is possible that some inmates gave their belongings to friends or relatives to look after before they entered the workhouse, meaning that the storage inventories are an under-representation of inmates' actual material wealth. Unfortunately, it is not possible to know the extent to which this happened; 
however, as section 3 points out, paupers who had a storage inventory made of their possessions were probably less likely to leave their possessions with friends or family than paupers who had their goods taken and kept by the parish. More commonly, the inmates would have sold a number of their possessions before they entered the workhouse to simply make do. As Beverley Lemire has recently argued, the poor obtained 'apparel, decorative accoutrements and household ware ... as stores of value ... with a view to their possible liquidity in cash or credit'. ${ }^{55}$ Thus when times were good the poor used and enjoyed these items, but when times were tough they sold them for food and other basic necessities. The autobiographies of poverty-stricken Joseph Mayett and Mary Saxby record this process. When Mayett was healthy and had regular work he was able to save money, but when bread prices were high he had to sell his possessions to make do. Saxby records the loss of her possessions on three occasions. In one instance most of her belongings were lost in a house fire, whereas on the other occasions she had to sell her possessions because she could not work due to an injury and after her husband had died. ${ }^{56}$ This survival strategy was probably especially important in the months before people entered the workhouse, when people started to struggle more and asked for more relief from the parish. The tables in this section quantify the frequencies of which particular items appear in both sets of the inventories. The figures collectively imply that this process of accumulating goods and then selling them when times were tough was prevalent in Beaminster, as the inmates represented by the storage inventories were much less likely to own most types of goods than the wider outdoor pauper population in Dorset.

Beds were one of the most valuable items that people owned, but were also very important to people at a more emotive level. Laura Gowing recently argued that beds 'were places for eating, talking, doing business, and seeing visions, as well as sleeping and sex' and 'were part of the family life cycle, the scene for birth, marital union, and death'. ${ }^{57}$ Table 1 demonstrates that this important item was common across both sets of inventories. Paupers recorded in the pauper inventories, though, tended to own better-quality beds and a greater average number of beds compared with those in the storage inventories. Of pauper inventories, 32 per cent recorded at least one feather bed compared with 9 per cent of storage inventories, for instance.

The ownership of one or more storage units implies that the paupers in question owned a number of possessions that needed to be stored, such as clothing and linen. Thus, the presence of relatively fewer boxes, cupboards and dressers in the storage inventories is possibly indicative of greater poverty (Table 1). Additionally, these units tended to be of inferior quality and were more commonly described as 'old' in the storage inventories. The pauper inventories for the most part also describe a greater variety of cupboards and dressers, such as dressers with shelves and double cupboards, and also record a greater quantity 
TABLE 1

Pauper ownership of select items 1770-1832 (\%): furniture

\begin{tabular}{lcc}
\hline \hline & $\begin{array}{c}\text { Beaminster workhouse storage } \\
\text { inventories }\end{array}$ & $\begin{array}{c}\text { Dorset pauper inventories } \\
\text { 1770-1822 }\end{array}$ \\
\hline Bed (all types) & 83 & 100 \\
Box (including coffers, & 61 & 73 \\
$\quad$ trunks, etc.) & & 0 \\
Chest of drawers & 0 & 41 \\
Cupboard & 13 & 32 \\
Dresser & 17 & \\
\hline \hline
\end{tabular}

Sources: Dorset History Centre (hereafter DHC) PE-BE/OV/7/1, DHC PE-BE/OV/7/5, DHC PE-BER/OV/1/10, DHC PE-BER/OV/11/2, DHC PE-BCN/OV/3/2, DHC PE-BBK/OV/1/1-2, DHC PE-CAM/OV/7/4-5, DHC PE-CDM/OV/1/1, DHC PE-EST/OV/1/1, DHC PE-HAM/OV/ 1/1, DHC PE-OBN/OV/1/1, DHC PE-SW/OV/1/5, DHC PE-TTG/OV/1/1 and DHC PE-WOR/ $\mathrm{VE} / 1 / 1$.

\section{TABLE 2}

Pauper ownership of select items 1770-1832 (\%): cooking-related items

\begin{tabular}{lcc}
\hline \hline & $\begin{array}{c}\text { Beaminster workhouse storage } \\
\text { inventories } 1817-1832\end{array}$ & $\begin{array}{c}\text { Dorset pauper inventories } \\
1770-1822\end{array}$ \\
\hline Cooking pot & 61 & 82 \\
Gridiron & 17 & 36 \\
Frying pan & 22 & 23 \\
Saucepan & 0 & 5 \\
Spit-related & 0 & 9 \\
\hline \hline
\end{tabular}

Sources: Dorset History Centre (hereafter DHC) PE-BE/OV/7/1, DHC PE-BE/OV/7/5, DHC PE-BER/OV/1/10, DHC PE-BER/OV/11/2, DHC PE-BCN/OV/3/2, DHC PE-BBK/OV/1/1-2, DHC PE-CAM/OV/7/4-5, DHC PE-CDM/OV/1/1, DHC PE-EST/OV/1/1, DHC PE-HAM/OV/ 1/1, DHC PE-OBN/OV/1/1, DHC PE-SW/OV/1/5, DHC PE-TTG/OV/1/1 and DHC PE-WOR/ $\mathrm{VE} / 1 / 1$.

on average. Chests of drawers were not mentioned in either set of inventories. They were owned by around a quarter of the 'middle sort' in the southwest between 1625 and 1740, but were most commonly owned among the richest quartile of this group. ${ }^{58}$ This suggests that chests of drawers may have been too expensive for most paupers to acquire in Dorset even by the early nineteenth century.

Table 2 records the ownership of cooking items. Cooking pots were 21 per cent more common in the pauper inventories and also tended to be owned in 
TABLE 3

Pauper ownership of select items 1770-1832 (\%): non-essential items

\begin{tabular}{lcc}
\hline \hline & $\begin{array}{c}\text { Beaminster workhouse storage } \\
\text { inventories }\end{array}$ & \multicolumn{2}{c}{$\begin{array}{c}\text { Dorset pauper inventories } \\
1770-1832\end{array}$} \\
\hline Book & 0 & 14 \\
Knives and forks & 9 & 23 \\
Looking glass & 0 & 32 \\
Pictures/prints & 0 & 5 \\
Tea-related items & 48 & 59 \\
Warming pan & 4 & 18 \\
Watch/clock & 0 & 9 \\
\hline
\end{tabular}

Sources: Dorset History Centre (hereafter DHC) PE-BE/OV/7/1, DHC PE-BE/OV/7/5, DHC PE-BER/OV/1/10, DHC PE-BER/OV/11/2, DHC PE-BCN/OV/3/2, DHC PE-BBK/OV/1/1-2, DHC PE-CAM/OV/7/4-5, DHC PE-CDM/OV/1/1, DHC PE-EST/OV/1/1, DHC PE-HAM/OV/ 1/1, DHC PE-OBN/OV/1/1, DHC PE-SW/OV/1/5, DHC PE-TTG/OV/1/1 and DHC PE-WOR/ $\mathrm{VE} / 1 / 1$.

greater quantities. Items used to cook food in diverse ways, such as frying, roasting, toasting or grilling, were also more commonly owned by people on outdoor relief. Gridirons, for instance, could be used in several versatile ways. Depending upon the distance to the fire, they could be used to toast food such as bread, or roast or grill meats. Overall, the evidence demonstrates that the range of possessions of people on outdoor relief was most varied, but nevertheless suggests that the fireplaces of most paupers remained basic. The majority of cooked meals would have been stew-, pottage- and porridge-type foods made with a cooking pot of some sort, whilst the consumption of roasted, grilled or toasted foods was less frequent. Muldrew recently argued that labourers' food was of a better quality than was previously thought by historical consensus. ${ }^{59}$ The results derived from the inventories of the poorest in society reveal little about the ingredients that paupers used, but suggest that the way in which food was cooked remained basic, probably often resulting in monotonous meals. ${ }^{60}$

The distinction between the two categories of inventories is especially prominent when it comes to the ownership of non-essential items, as paupers on outdoor relief were significantly more likely to own one or more of these items (Table 3). ${ }^{61}$ Several of the goods demonstrate that some people were even able to decorate their homes. One man owned eight pictures, for instance, and around one-third owned a looking glass. The presence of knives and forks suggests that mealtimes for some paupers had become more formalised and ritualised through the association that cutlery had to dinner 'manners' and individual courses. ${ }^{62}$ Most notably, tea-related items were commonly owned by 
paupers, suggesting that tea had become a mass-consumed commodity. ${ }^{63}$ The range of tea items found in either type of inventories was limited though. The most common items were tea kettles and teapots, and very few people owned items such as tea chests and tea waiters. ${ }^{64}$ Most of our current knowledge of the material wealth of the poor is based on information derived from London or the Home Counties. These results demonstrate that paupers in the southwest could also own non-essential items by the late eighteenth century, but that there could be significant variations in the ownership of these goods, depending upon whether the pauper was on outdoor relief or about to use the workhouse. It is, however, important to point out that in relative terms all paupers remained materially poor compared with the middle and upper classes of the eighteenth and nineteenth centuries. ${ }^{65}$

\section{WORKHOUSE MATERIAL LIFE}

The use of workhouse inventories over a number of years allows the historian to uncover how comfortable workhouses were and understand how this varied over time. Moreover, by linking these inventories to wider sources such as workhouse accounts, rules and dietaries, it is possible to gain a more detailed understanding of what life was actually like in the workhouse than previous historical studies have managed. Unless otherwise specified, the findings for this section come from Beaminster's workhouse inventories dated 1785, 1822, 1827 and 1830. These are occasionally supplemented by two less detailed workhouse inventories, dated 1796 and $1818 .{ }^{66}$ This section argues that material life in the workhouse was adequate and that inmates were well fed. The parish would sometimes adjust the layout of the rooms and goods within the workhouse in accordance with the needs of its current inmates and to improve its own management of the house. However, more fundamental to the parish was maintaining order and discipline, and the parish arranged rooms and material goods to this aim. A home furnished with both basic goods and non-essential items was achievable for some on outdoor relief and offered a better alternative to the workhouse. Most paupers would have probably strived towards this. ${ }^{67}$

Most parish workhouses were created from existing cottages. ${ }^{68}$ Beaminster workhouse, on the other hand, was purpose-built in 1766 after the previous one had burnt down. ${ }^{69}$ Despite this, the functions of many of the rooms were not static and sometimes changed in response to the needs of inmates and officials. The workhouse probably stood at 3 storeys tall and had around 24 rooms in use. Throughout the 1780s and 1830s there were around 7-10 rooms which had beds in them. Men and women were put into separate dormitory-style bedrooms and children most probably slept in the garret rooms. The layout of furniture in each bedroom was very formulaic and 
bare, generally containing no more than beds, bedding and commodes. There were constantly one or two warming pans in the workhouse over the period but this would not have been enough for everybody. Presumably they were used for the sick. Candlesticks and lanterns were rarely recorded in bedrooms, suggesting that officials wanted inmates to sleep as soon as they got to their beds. There were also bedrooms for 'idiots', 'invalids' and the 'insane'. The workhouse may have tried to keep some of these inmates self-contained. Most bedrooms contained no more than a bed and a commode; however, the 'invalid's room' also included seating, tables, and cooking- and hearth-related items. The room was almost certainly arranged in this manner due to the mobility problems that these inmates had in getting to mealtimes and other parts of the workhouse. By 1827 a room had been converted into a bedroom for married couples and there was also a room solely occupied by 39 -year-old Thomas Swaffield. He was described as 'Insane' in 1820 so may have been using the room in isolation as he was a danger to other inmates. ${ }^{70}$ Clearly, sleeping arrangements were basic, but the types of bedrooms that inmates used sometimes changed in response to their needs, or were changed by officials who wanted to effectively manage and regulate the workhouse.

The number of beds fluctuated and was unsurprisingly highest in 1822 when the number of inmates reached its peak. In 1785 almost every bed was made of flock and by the 1820 s the beds were made from a mix of flock and straw. By dividing the number of beds, bedding and pillows/bolsters by the size of the workhouse population, one can see how these items were shared. Beaminster workhouse at any time would approximately sleep two people per bed, along with one or two items of bedding and one or no pillows/bolsters each. Bed sharing in homes and workhouses was common during the period. Beaminster may have been fairly generous compared with other institutions, such as Ovenden workhouse in Yorkshire which slept around three in a bed. ${ }^{71}$ The figures should be treated with caution though, as bed sharing differed by type of inmate. Wisbech workhouse in 1720s Cambridgeshire, for instance, slept the elderly two to a bed and children three to a bed. ${ }^{72}$ Recent research has highlighted the importance of a private fireside for turning a house into a 'home' in eighteenth- and nineteenth-century society. ${ }^{73}$ The evidence derived from the bedrooms in Beaminster workhouse suggests that there were limited opportunities for such privacy and little scope for the personalisation of space. Married couples were able to share beds from 1827, but in a room with other married couples, and most other inmates would have had to share beds and commodes with other people. Some workhouses, such as Rolvenden, Kent, allowed inmates to use boxes with locks to store personal and sentimental belongings. ${ }^{74}$ No such items were recorded in the workhouse inventories from Beaminster, suggesting that they were not allowed, in a similar manner to other workhouses such as Wimbledon in Surrey. ${ }^{75}$ 
In 1785 the parish attempted to make the poor profitable through their labours. There was a workroom and spinning shed which collectively contained 21 wool turns, 7 turns and 10 reels, among other work-related items. Inmates would work using these items six days a week 'for the Benefit of the Parish' in return for a small proportion of the profits. ${ }^{76}$ By the 1820 s the inventories show that the workhouse contained very few textile-related items. In 1822 there were 12 items connected to textile manufacture and by 1830 there were only 2 quilting frames, which were probably in storage and only used to occasionally serve the house. Moreover, by the 1820 s the spinning shed was used to store gardening/agricultural tools and the workroom had been converted into a dining room. This decline in textile-related items is unsurprising, especially considering the fragile state of the local weaving industry. ${ }^{77}$ Workhouse rules dated 1834 state that each inmate was allowed 'the sum of three Halfpence out of every Shilling as an encouragement for industry' ${ }^{78}$ and to further this aim the parish employed inmates in other ways. From 1818 a small number of children and male and female adults knitted worsted and yarn, ${ }^{79}$ and a minority were probably employed in parish work schemes such as road building or the roundsman system. ${ }^{80}$ Meanwhile, the remainder probably worked towards the general running and maintenance of the house. In each workhouse inventory from 1822 the number of items used for gardening workhouse grounds increased, and washing, cleaning and cooking items remained prominent. There were also areas solely devoted to running the house, such as the garden for growing food and the washroom. Although most workhouses had abandoned their attempts to make inmates profitable by the early nineteenth century, ${ }^{81}$ the experience of Beaminster demonstrates that the authorities still considered it important that inmates did not become idle and get a free stay.

During the late eighteenth century meals were eaten in the dining room. Inmates would sit on one of four forms (benches) around long oak tables. Dishes were measured out on scales and served onto a wooden dish, wooden bowl or trencher, to be eaten with hands or a spoon. Presumably the inmates queued up and were given their food. There were seven knives and five forks recorded in the pantry in 1785 and a 'few Delf Plates' in the kitchen in 1822; however, such negligible numbers suggest that they were used by workhouse officials and not by inmates. Mealtimes were simple and regimented. By the 1820 s this form of dining continued, but instead most inmates ate off earthenware dishes. There was also a dinner bell, which would have been used to call people to mealtimes. Rules stated that governors should 'watch strictly the conduct of the Inmates ... to use their utmost endeavour to prevent the Selling or otherwise desposing of their daily rations of food or clothing'. One of the main punishments used by officials involved giving inmates only bread and water or nothing at all. ${ }^{82}$ Other workhouses also tried to use the 
dining room and food to discipline inmates and maintain order. Leeds, for instance, made inmates eat in silence and say thanks after every meal. If inmates did not abide by these rules then they lost their next meal and if they told lies they had to stand on a chair in the dining room "with a Paper fixed on his or her Breast, whereupon shall be written, Infamous Liar' ${ }^{83}$ Dining rooms were also often the location where rules were hung up or read aloud to inmates. ${ }^{84}$

Within the relatively sparse literature on workhouses of the old poor law, historians have often given most attention to food. ${ }^{85}$ Most of the research, however, has tended to not use workhouse inventories and instead use sources such as dietaries, which only present an idealised version of what the workhouse wanted to feed people and not necessarily what they actually ate. Through the use of multiple sources such as workhouse inventories, workhouse accounts and dietaries, it is possible to refine this current state of knowledge and uncover what food was actually eaten by inmates and find how it was cooked over a period of time. ${ }^{86}$ The kitchen contained a range of implements which could be used to produce a decent variety of food. There were varying quantities of boilers, cooking pots and skillets over the entire period to boil or stew food. By the 1820s the numbers of frying pans and gridirons had increased and there were also three saucepans and a kitchen range, which would have enabled cooks to produce more diverse and complicated meals. Saucepans, for instance, were less cumbersome than large cooking pots, heated quickly and could be used to make sauces. ${ }^{87}$ Inmates were supposed to receive three meals a day except on Sundays, according to a dietary from 1774. Nearly every meal included bread and was generally accompanied with milk broth and oatmeal. Two meals a week were served with vegetables from the garden and three days a week with bacon or less often beef. Adults received more than children each meal. ${ }^{88}$ Workhouse accounts demonstrate that this dietary was roughly kept to; however, the parish additionally purchased currants, treacle, pepper and 'spice' during the 1770s and ginger and mustard in the 1790s. Sugar, vinegar and salt were purchased in large quantities, which could have been used to flavour food and preserve it using the salt casks, pickling pots and meat tubs found in the workhouse inventories. ${ }^{89}$ So food, however seemingly repetitive and dull, could be flavoured by inmates and cooks. By the 1820s food provision had continued to improve. Pork and beef were bought more regularly, and occasionally mutton, offal, veal and fish were bought in small quantities. The workhouse also kept pigs. Milk, oatmeal and bread continued to be staples and potatoes, cheese, flour, peas, carrots and turnips were also available..$^{90}$ During the 1820 s there was one copper tea kettle noted in the workhouse inventories; however, tea probably remained a preserve of the sick and officials and members of the vestry who used a room in the workhouse for meetings. ${ }^{91}$ As shown above (see section 5), tea was mass-consumed by the majority of the outdoor poor in Dorset, 
but in the workhouse inmates had to forfeit this commodity. It has been argued by historians that workhouses in various parts of the country could be relatively generous in the food that they gave inmates. ${ }^{92}$ Similarly, the Royal Commissioners who investigated the state of the poor laws in the early 1830s claimed that workhouse food was of a better quality than the poor could generally manage in their own homes. ${ }^{93}$ Taking cooking utensils, dietaries and ingredients into consideration, the example of Beaminster finds that a wide variety of meals could be made for inmates. With the exception of tea, workhouse provisions were of a better quality and variety than paupers represented by the storage inventories and pauper inventories could generally manage.

During the late eighteenth century, around two-thirds of inmates were elderly and the remainder were young. ${ }^{94}$ Consequently there were three workhouse hospital rooms which the elderly probably used most, but there were no rooms primarily devoted to the young. By 1818 when the proportion of children in the workhouse had significantly increased, a schoolroom for the purposes of knitting and industry was added. ${ }^{95}$ One of the hospital rooms probably gave way to this, as there was less need for so many. ${ }^{96}$ Pupils would sit on long forms and used lap tables or would sit around a large table. One workhouse inventory reported a number of schoolbooks in the room. Unfortunately, it is unclear what types of schoolbooks they were, but at the very least they would have helped the young's literacy. There were also shoemaking tools in the schoolroom, showing that the workhouse also tried to teach the young a trade. By 1830 the schoolroom was only used by boys. Adjoining the workhouse a new subscription-funded girls' school was added to teach girls from the workhouse and the wider area over the age of 5 years old 'needle work, knitting, reading and ... moral and religious duties'. Books, including bibles, pens and writing paper were purchased for the girls and pins and sheets were purchased for them to work on. The school was reportedly established due to the 'extreme idleness and ignorance ... which prevails among many of the children of the Parish ... especially of the Children in the Workhouse'. ${ }^{97}$ It is questionable how adequate and balanced the education for workhouse children was before the 1830s. Nevertheless, the workhouse offered children at least some education, which many would not have otherwise had. ${ }^{98}$

The formulaic layout of many of the rooms in the workhouse suggests that order and discipline were important to the parish. Workhouse rules from 1785 and 1834 corroborate this, by laying out rules to enforce cleanliness, punish theft and prevent begging when people left the workhouse to worship on a Sunday. ${ }^{99}$ One of the methods of punishing inmates was through the use of the 'Blind House', which was in use from at least the 1750s. The room only contained a bed. When inmates were disorderly or idle they were put 
there in isolation on a diet of only bread and water or nothing, and were not allowed to leave until they had served their punishment. ${ }^{100}$

The parish from the 1750 s to the end of the period made inmates wear uniforms and badges. ${ }^{101}$ Unfortunately, it is unclear what the exact uniform was. Various workhouse accounts record the purchasing of large quantities of worsted, calico, linsey and dowlas, and in smaller quantities coloured cotton and fustian from contractors. Some items were also bought off the peg such as trousers, shirts, stockings, waistcoats, breeches, petticoats, hats and shoes. ${ }^{102}$ From at least 1766 , the clothes and linen that paupers brought into the workhouse with them were kept in a storeroom, ready to be taken away if they left. This was very similar to the way in which their household possessions were treated, although their clothes and linen were also cleaned. ${ }^{103}$ Given that on numerous occasions the parish reiterated its desire to make inmates wear a uniform, ${ }^{104}$ this strongly suggests that there was a clear intention to distinguish the inmates from the wider population and to label them as dependants of the workhouse. This policy could have also been adopted to control the movement of inmates, as people would have been technically stealing if they left the workhouse in their uniform without permission. The authorities continued their efforts to regulate the appearance of inmates and signal their dependency by making it compulsory in 1834 for inmates to wear no earrings or hair ornaments and to keep their hair 'decently short'. ${ }^{105}$ For men this meant regular head shaving. ${ }^{106}$ Of course, this could have been used to curtail the spread of lice, but because the parish went to great lengths to control other aspects of people's appearance, it is likely that this was also another instrument that officials used to control inmates. The use of uniforms was not universal in other workhouses, but in the case of Beaminster the quality and range of clothing were more than adequate compared with the clothing given to paupers on outdoor relief, though not to the same standard of an ordinary labourer. ${ }^{107}$ Yet what the uniform represented was a completely different matter.

\section{THE LIFE HISTORIES OF PAUPERS ENTERING THE WORKHOUSE108}

The life histories of people from the storage inventories will now be assessed. This research adds to the literature on agency and the economy of makeshifts of the poor by outlining why people entered the workhouse and how some groups used the workhouse strategically for temporary periods of time. ${ }^{109}$ Of all storage inventories, 65 per cent were made for married couples with dependants, whilst the remaining 30 per cent were made for people who were either single or widowed. Just over half of these also had dependants to support. ${ }^{110}$ It was generally life-cycle- and work-related problems that drove these people into the workhouse, such as sickness and underemployment; however, in two examples the main reason for admission to the 
workhouse was because the household breadwinner had been imprisoned. This meant that the family economy was fatally undermined and that the prisoners' wives and children had to seek further relief.

The average age of the married men and women with storage inventories was 45 and 38 years old, respectively. Only two married men were aged over 60 years old and five were no older than 32 years old. On average, these married couples had nearly four children each and most were below 10 years old at an average of around 6 years old. Most children were therefore too young to work, leaving it to the parents or the parish to support them. The majority of these male breadwinners were either labourers or weavers, which were difficult trades from which to make a living, ${ }^{111}$ and many of these families were suffering from bouts of illness. The parish had used casual relief and numerous make-work schemes such as the roundsman system and road building to relieve the able-bodied from around the mid-1790s, so clearly preferred to relieve this group in their own homes on a casual basis and only used the workhouse as a last resort.

The single or widowed people with storage inventories were all women except one. Just over half of these brought children with them and were themselves generally aged in their 50s. The remainder of single or widowed women who did not bring children with them were in their 60 s or 70 s. Again, the parish did not want to relieve these inmates indoors for an extended period of time, but it was often much tougher for this group to regain their independence. Eventually, all of the single or widowed (with or without children) became long-term inmates in the workhouse, except Eleanor Newbury who instead spent years frequently moving in and out of the house. Wages were lower for women and children in general, and without a male breadwinner who typically earned more money they struggled to be self-sufficient. This group was also generally older, meaning that work was more physically demanding and worse paid than it was for younger women. ${ }^{12}$ Many were also suffering from various illnesses.

Generally, the inmates who had a storage inventory made of their possessions used the workhouse for less than a year, averaging 204 days. This led to a high turnover of inmates. Some stays were short such as the Browns who only stayed nine days. The Clares by contrast on one occasion used the workhouse for 654 days. Sometimes the breadwinner would leave first and the family would follow a few months after. Perhaps this was to allow the breadwinner to find work and reinstate his/her independence without the added pressure of supporting their family. This short-term use of the workhouse was beneficial for married couples as nearly all of them were generally able to support themselves through their own means and occasional supplements of casual relief after they left. Inmates who were single or widowed, however, either never regained their independence or eventually became 
long-term residents of the workhouse several years later. Unfortunately, Beaminster's sources do not discuss the negotiation process that must have taken place between officials and paupers in deciding a strategy on how and when to leave the workhouse. People needed permission to leave and in most cases inmates immediately started receiving some sort of outdoor relief once they did. So there must have been some negotiation and compromise made between the two parties. ${ }^{113}$ Relieving a pauper in the workhouse cost around four times as much as it did on outdoor relief, ${ }^{114}$ so most parishes naturally wanted to avoid using the workhouse for prolonged periods of time wherever possible. Moreover, the majority of people probably strived towards living independently since a furnished home with varied possessions without the discipline of the workhouse was achievable for some on outdoor relief, as the results from section 5 demonstrate. Thus, the use of the workhouse for short periods of time was beneficial and desirable to both the parish and most paupers. These findings will now be developed through the perspective of one representative able-bodied inmate who was married with children and another who was widowed with children.

\section{CASE STUDIES}

\subsection{Hiram Brown}

Hiram and his wife Elizabeth were both 32 years old when they entered the workhouse in April 1830. They brought their five children with them: Solomon aged 13-14 years old, John aged 11 years old, Harriet aged 8 years old, Elizabeth aged 5 years old and Mary aged 2 years old. Hiram's occupation on his children's baptism records changed frequently, ranging from a labourer to different types of weaving and flax dressing. This suggests that Hiram had to keep changing his trade to make do. Between 1817 and 1827, Hiram and his family received very infrequent casual relief during temporary periods of sickness and unemployment. By 1828, Hiram's troubles had escalated and he started to receive more regular casual relief from the parish. In the winter months before the family entered the workhouse, Hiram was given significant amounts of relief as he could not find work due to the frosty weather. After the frost had subsided Hiram was employed by the parish digging flint on a hillside and he and his wife also received relief for sickness. Hiram around this time was earning around 8 shillings per week, whilst his eldest son was earning between 2 shillings to 2 shillings 6 pence a week. This was fairly typical of other labouring families from the area, but with illness afflicting the family and the infrequency of employment, the family had to turn to the workhouse.

Compared with other storage inventories, the Browns had a relatively large quantity and variety of goods stored within the workhouse (Figure 4). 


Inventorey of Hiram Browns Goods $5^{\text {th }}$ Apr' 1830
2 Bedsteeds 1 Tick \& 1 Cordbottom, 1 Dust Bed Tie, one Blankit,
2 Sheets, one Dust Bolster, one Loome, 2 Tabels, one Set of Shelves
2 Furms, one Iron Pot, 2 Pitch forks a Picks one Quillingturn
one Swift \& Stock, one Back Crook, one Pigs Trow, one Chaire,
ene-Box, one Paire of Tempels, one hamer, 1 Fring Pan,
1 Paire of Bellows, Paire of Pot hangers, a Smel hanging C[upboard?]
one Choping Cook
Taken out the $15^{\text {th }}$ Apr' By Hiram Brown his Wife and
Children this Day

FigurE 4. Storage inventory of Hiram Brown, 1830. Source: Dorset History Centre PE-BE/ $\mathrm{OV} / 7 / 1$.

Nevertheless, they owned very few household goods apart from two beds and rudimentary items such as bedding, a cooking pot, bellows, tables and seating. Interestingly, the inventory includes a range of work-related tools, such as a loom, pitchforks and picks. This reflects the variety of jobs that Hiram did to make ends meet within the insecure local economy. The Browns used the workhouse for nine days and on the tenth day they reclaimed their possessions. Whilst there, the parents would have had access to the medical help that they needed. After leaving the workhouse the Browns received casual cash and food allowances from the parish during bouts of sickness and unemployment. Consequently their problems were not solved by this temporary stay, but the workhouse nonetheless offered them a flexible refuge which they could leave when they were ready to. Despite many of the poor disliking the workhouse and their loss of independence, ${ }^{115}$ it at least offered them shelter where they could sleep, seek medical help, eat a decent meal and store their possessions. Moreover, because the parish helped people in this way it helped parishioners keep their independence in the long term.

\subsection{Betty Pomery}

The example of Betty Pomery is representative of other single or widowed mothers from the storage inventories. Betty was 51 years old when she entered the workhouse for the first time in July 1820 and had five children with her: Elizabeth aged 17 years old, Eliza aged 15 years old, Mary aged 13 years old, John aged 10 years old and Harriet aged 7 years old. She had recently become widowed after her 51-year-old husband William died three weeks prior to this. Unfortunately, there are two people called William Pomery in the 
(a)

\begin{tabular}{|l||l|}
\hline \multicolumn{1}{|c|}{$28^{\text {th }}$ July 1820} & \multicolumn{1}{c|}{ Octr $15^{\text {th }}$} \\
Goods of Betty Pomery's \\
Brought in the house With Her
\end{tabular}

Figure 5. Storage inventories of Betty Pomery, 1820-1821. Source: Dorset History Centre $\mathrm{PE}-\mathrm{BE} / \mathrm{OV} / 7 / 1$.

overseers' accounts so it is not possible to track his relief precisely; however, both of them received casual relief almost on a monthly basis for unemployment and for doing parish work, such as digging and road building. The amounts that both received from the parish were considerable. In most months both were paid over $£ 1$ and sometimes over $£ 2$. Betty also received relief in her own name for sickness, so clearly the family was struggling on several fronts. It was when William died that the already fragile family economy ultimately toppled, resulting in Betty and her five children moving to the workhouse only three weeks later.

The storage inventory taken of Betty's goods in July 1820 notes a small number of possessions but enough to run a household at a basic level (Figure $5 a$ ). There was also a spinning turn which could be used to make thread to sell. Nearly eight months later the Pomerys left the workhouse with their possessions, except the eldest daughter Elizabeth who had left in January 1821 to presumably go into service. Betty immediately started receiving 2 shillings a week from the parish and also earned 1 shilling per week in some kind of employment. This was much less than William received when he was alive and unfortunately there was little work available for the children. The parish seemed to favour giving parish-organised work and money for bouts of unemployment to men rather than women and children. In all, Betty's income was insufficient to maintain a household with four children and seven months later the family re-entered the workhouse. The parish and Betty again assumed that this was for a temporary period as a second storage inventory was made. The goods listed in this inventory were much fewer and more basic, suggesting that it must have been very difficult to run a household (Figure $5 b$ ). The Pomerys still had a bed, a spinning turn and boxes; however, 
they no longer owned any cooking utensils and there were fewer blankets and pillows. This strongly suggests that in the seven months between the inventories Betty had to part with her goods to make do and support the family. ${ }^{116}$ There is a small chest and stool in the second inventory that do not appear in the first. Perhaps the stool was an inferior replacement of the two chairs they had owned earlier and the chest was a gift.

In the years that followed, Betty's children left the workhouse one by one when they became old enough. Betty never regained her independence. The fact that these storage inventories were made suggests that both Betty and the parish did not want the workhouse to be a long-term solution. However, as a result of the death of her husband, bouts of illness and insufficient income, Betty struggled to make do. This is a fairly representative example of other single or widowed people with children, and shows that it was much more difficult for this group to regain their independence compared with able-bodied inmates such as Hiram Brown.

\section{CONCLUSION}

Using the case study of Beaminster and Dorset more widely, this article has examined the poor's material wealth, their lives inside and outside the workhouse, and their strategic use of the workhouse. The evidence demonstrates that workhouses were not places of material abundance as the Royal Commissioners' report from 1834 suggested, but were simply adequate to inmates' basic material needs. It was only in terms of food that inmates could expect to receive better provisions than they could when living independently outside the workhouse. A picture also emerges of an institution which was more organised and orientated towards discipline than the Commissioners suggested. Although the parish was willing to adapt the layout and use of some of the rooms in accordance to its current profile of inmates, the underlying principle of the whole system of indoor relief was order and discipline, and the material goods of the workhouse were used to help maintain this. Mark Blaug, who principally studied the allowance system, argued that the Commissioners' report was 'a wildly unstatistical' document which 'deliberately selected the facts so as to impeach the existing administration on predetermined lines'. ${ }^{117}$ The example of Beaminster in a similar manner provides important empirical evidence that the Commissioners also selectively used their findings from workhouses, in order to paint an image of an inadequately administered and overly generous institution and thus encourage legislators to enact an amended poor law act.

Historical research on the material wealth of the poor has often failed to identify the circumstances of the poor before an inventory was made. Green's study of the poor in Norfolk, for example, did not link the individuals 
in his sample of inventories to wider sources and so was inclusive of a number of people who were not on poor relief. Through the assessment of three types of inventories and a wide range of parish sources, this article has demonstrated the importance of contextualising the individuals from inventories and highlighted the danger of seeing the poor as one homogeneous group. Analysis of storage inventories, for instance, has suggested that inmates were struggling in the period immediately before they entered the workhouse and that their material goods had diminished in number and value as a result. By contrast, paupers on outdoor relief were more able to maintain a home and some were even able to own non-necessities and more decorative goods. Through this more nuanced perspective on the poor, this research has begun to address a significant gap in the historiography which has seen the poor being repeatedly ignored as the subject of study in favour of middle- and upper-class consumers.

Workhouse inmates were not passive agents and had some control over the nature of relief they received. Even women and the single or widowed, despite their deprived economic situation, showed some element of agency as they were able to negotiate the temporary storage of their possessions, despite the likelihood that most of them would become long-term dependants of the workhouse. The Commissioners' report from 1834 suggested that the ablebodied increasingly used the workhouse as they preferred it to their own homes. If the poor really did choose to use the workhouse in this manner, this would have been a form of pauper agency; however, the evidence derived from Beaminster shows a different pattern of agency. Instead, the able-bodied would enter the workhouse to receive medical help or during periods where there were few local employment opportunities, and would then leave the workhouse when their health had recovered or when there was more work available, and reclaim their belongings from the parish. The nature of poor relief in many workhouses was therefore not simply a matter of the poor taking advantage of a system when they could, or of the parish oppressing the poor; there was instead an element of negotiation between the two parties. This negotiation was essentially built on self-interest: officials were most interested in preventing the pauper from becoming a long-term dependant of the parish and in limiting further rises in the poor law bill, whilst the paupers used the workhouse strategically as they needed it and because it suited them at that moment in time. This was a form of negotiation between the two parties and demonstrates that there was some element of trust, discretion and agency. Further research on other workhouses is needed to establish how widespread these patterns of behaviour were; however, the case study of Beaminster strongly suggests that the nature of indoor relief was much more complex than the Commissioners argued. 


\section{ACKNOWLEDGEMENTS}

This research was conducted under the kind support of the Arts \& Humanities Research Council (grant number ah/k503101/1). An earlier draft of this paper was given at the University of Leicester's Centre for English Local History in early 2014 and I would like to thank the audience for their questions and comments. I am also grateful to the editors and reviewers for their insightful feedback. Above all, I would like to thank Claire Bishop, Pete King and Roey Sweet for their support and advice which have helped to greatly improve this article.

\section{ENDNOTES}

1 Lynn MacKay, 'A culture of poverty? The St. Martin in the Fields workhouse, 1817', Journal of Interdisciplinary History 26 (1995), 209-31.

2 On these opposing views, see Anne Digby, Pauper palaces (London, 1978), 1-2.

3 All quotations from British Parliamentary Papers (hereafter BPP), 1834, XXVII.1, Report from his Majesty's commissioners for inquiring into the administration and practical operation of the poor laws, 29.

4 Two of the most accessible are Kathryn Morrison, The workhouse: a study of poor-law buildings in England (Swindon, 1999), 43-52; and M. A. Crowther, The workhouse system 18341929: the history of an English social institution (London, 1981), 11-29.

5 E. M. Hampson, The treatment of poverty in Cambridgeshire 1597-1834 (Cambridge, 1934), 79-80 and 108-9; and Samantha Williams, Poverty, gender and life-cycle under the English poor law 1760-1834 (Woodbridge, 2011), 49-50. Also see Pamela Sharpe, Population and society in an east Devon parish: reproducing Colyton, 1540-1840 (Exeter, 2002), 90 and 237; and Judith Hill, 'Poverty, unrest and the response in Surrey, 1815-1834' (unpublished $\mathrm{Ph} . \mathrm{D}$. thesis, University of Surrey, 2006), 214-15.

6 Susannah R. Ottaway, The decline of life: old age in eighteenth-century England (Cambridge, 2004), 254-8 and 261-4; and Alannah Tomkins, The experience of urban poverty, 1732-82: parish, charity and credit (Manchester, 2006), 50-69.

7 Ottaway, Decline, 258-9.

8 On the 'crisis' years, see Peter Dunkley, The crisis of the old poor law in England 1795-1834: an interpretive essay (London, 1982).

9 Examples of parishes like this include Atherton and Turton in Lancashire. See May 1747 overseers' entry in Wigan Archives Service (hereafter WAS), Leigh TR/Ath/C/2/29 and Bolton Archives and Local Studies Service, Bolton PTU/6.

10 Francis Hill, Georgian Lincoln (Cambridge, 1966), 161; and Ottaway, Decline, 254-5.

11 On pauper inventories, see my forthcoming thesis provisionally titled: 'Material lives of the poor: a regional perspective, c.1680-1834'; Peter King, 'Pauper inventories and the material lives of the poor in the eighteenth and early nineteenth centuries', in Tim Hitchcock, Peter King and Pamela Sharpe eds., Chronicling poverty: the voices and strategies of the English poor, 1640-1840 (Basingstoke, 1997), 155-91; and Barbara Cornford, 'Inventories of the poor', Norfolk Archaeology 35 (1970-1973), 118-25.

12 For example, Ottaway, Decline, 247-76; Jeremy Boulton and Leonard Schwarz, “"The comforts of a private fireside"? The workhouse, the elderly and the poor law in Georgian Westminster: St. Martin-in-the-Fields, 1725-1824', in Joanne McEwan and Pamela Sharpe eds., Accommodating poverty: the housing and living arrangements of the English poor, c.1600-1850 (Basingstoke, 2011), 221-45; Kevin P. Siena, Venereal disease, hospitals and the urban poor: London's “foul wards”, 1600-1800 (Woodbridge, 2004), 135-80; Jonathan Reinarz and Leonard Schwarz eds., Medicine and the workhouse (Rochester, 2013); Tim 
Hitchcock, "'Unlawfully begotten on her body": illegitimacy and the parish poor in St Luke's Chelsea', in Hitchcock, King and Sharpe, Chronicling, 70-86; and Alysa Levene, The childhood of the poor: welfare in eighteenth-century London (Basingstoke, 2012), 107-29.

13 Tim Hitchcock, 'The English workhouse: a study of institutional poor relief in selected counties, 1696-1750' (unpublished D.Phil. thesis, University of Oxford, 1985), 193-210; Hitchcock, 'Unlawfully', 73-4 and 79-80; MacKay, 'Culture', 226-8; Jeremy Boulton, “'It is extreme necessity that makes me do this": some "survival strategies" of pauper households in London's West End during the early eighteenth century', International Review of Social History 45, S8 (2000), 47-69, here 52-3; Boulton and Schwarz, 'Comforts', 230-2 and 239; David R. Green, 'Pauper protests: power and resistance in early nineteenth-century London workhouses', Social History 31 (2006), 137-159; David R. Green, Pauper capital: London and the Poor Law, 1790-1870 (Farnham, 2010), 157-87; and Steven King, Poverty and welfare in England 1700-1850: a regional perspective (Manchester, 2000), 163-4. For examples beyond England, see Catherine Lis and Hugo Soly, "Total institutions" and the survival strategies of the laboring poor in Antwerp, 1770-1860', in Peter Mandler ed., The uses of charity: the poor on relief in the nineteenth-century metropolis (Philadelphia, 1990), 53-5; and Giovanni Gozzini, 'The poor and the life-cycle in nineteenth-century Florence, 1813-59', Social History 18 (1993), 299-317, here 309-10 and 312-13. For research on agency and other makeshift economies available to the poor, see the papers in Henry French and Jonathan Barry eds., Identity and agency in England, 1500-1800 (Basingstoke, 2004); and Steven King and Alannah Tomkins eds., The poor in England 1700-1850: an economy of makeshifts (Manchester, 2003).

14 Geoffrey W. Oxley, Poor relief in England and Wales 1601-1834 (London, 1974), 91. Also see Hill, 'Poverty', 192-4.

15 Quoted from: Pigot and Co. 's national commercial directory (London, 1830), 274.

16 The information for this paragraph collectively comes from: Ibid., 274-5; Dorset History Centre (hereafter DHC), Dorchester PE-BE/MI/3/1; BPP, 1833, XXXI.1, Census of England and Wales, 1831, 146-7; Richard Hine, The history of Beaminster (Taunton, 1914), 303-22 and 443-51; Marie de G. Eedle, A history of Beaminster (Chichester, 1984), 69-112; George A. Body, 'The administration of the poor laws in Dorset 1760-1834' (unpublished Ph.D. thesis, University of Southampton, 1968), 2-60; Samantha A. Shave, 'The dependent poor? (Re)constructing the lives of individuals "on the parish" in rural Dorset, 1800-1832', Rural History 20, 1 (2009), 69-97, here 73-5; and K. D. M. Snell, Annals of the labouring poor: social change and agrarian England, 1660-1900 (Cambridge, 1985), 375-7.

17 DHC PE-BE/OV/7/1 and DHC PE-BE/OV/7/5. A further four inventories have been set aside because they were made for people who did not appear on admissions records and so did not enter the workhouse.

18 See sections 7 and 8 for more information on these categories of inmates.

19 Hill, Lincoln, 161; and Jeremy Boulton, “"Turned into the street with my children destitute of every thing", the payment of rent and the London poor, 1660-1850', in McEwan and Sharpe, Accommodating, 31.

20 Anonymous, An account of several work-houses for employing and maintaining the poor (London, 1725), 61.

21 See the case study of Betty Pomery (section 8.2), for example.

$22 \mathrm{DHC}$ PE-SPV/OV/8/2.

23 Anonymous, An account of several work-houses, 65-6.

24 F. M. Cowe ed., Wimbledon vestry minutes, 1736, 1743-1788 (Guildford, 1964), 58-9.

25 Philip Anderson, 'The Leeds workhouse under the old poor law: 1726-1834', Publications of the Thoresby Society 17, 2 (1980), 98.

26 Ottaway, Decline, 254-5. 
27 For example, in Dartford, Kent, a parish official visited the home of Widow Brown and suspected that she had had a 'mock sale' to avoid the goods being taken and sold by the parish towards her support. See Elizabeth Melling ed., Kentish sources: IV the poor (Maidstone, 1964), 104. Also see King, 'Pauper inventories', 158.

28 Hitchcock, 'English workhouse', 213-14; Thomas Ruggles, The history of the poor: their rights, duties and the laws respecting them: in a series of letters (London, 1797), 324-31; Ottaway, Decline, 247-76; and Digby, Palaces, 1-2.

29 Melling, Kentish sources, 103.

30 The inventories were made in: Bere Regis (3), Buckland Newton (1), Burton Bradstock (3), Canford Magna (3), Caundle Marsh (3), East Stour (1), Hammoon (1), Oborne (2), Swanage (1), Tarrant Gunville (3) and West Orchard (1). From DHC PE-BER/OV/1/10, DHC PE-BER/OV/11/2, DHC PE-BCN/OV/3/2, DHC PE-BBK/OV/1/1-2, DHC PE-CAM/ OV/7/4-5, DHC PE-CDM/OV/1/1, DHC PE-EST/OV/1/1, DHC PE-HAM/OV/1/1, DHC PE-OBN/OV/1/1, DHC PE-SW/OV/1/5, DHC PE-TTG/OV/1/1 and DHC PE-WOR/VE/1/1.

31 For an extended discussion on using pauper inventories from Dorset and other counties to study the material lives of the poor, see my forthcoming thesis. Also see King, 'Pauper inventories', 155-91; and Cornford, 'Inventories', 118-25.

32 Found in DHC PE-BE/OV/1/3, DHC PE-BE/OV/7/1 and DHC PE-BE/OV/7/2.

33 DHC PE-BE/OV/7/10.

34 Cowe, Wimbledon, 58.

35 Workhouse inventories from 1820s Beaminster record a 'Burn Mark' which may have been used to brand parish goods.

36 Michael Nolan, $A$ treatise of the laws for the relief and settlement of the poor, Volume 2, 4th edn (London, 1825), 390.

37 For a transcription of this will, see Hine, The history of Beaminster, 184-6.

38 DHC PE-BE/OV/1/1-7. Also see Hine, The history of Beaminster, 184-97; and Eedle, A history of Beaminster, 113-23.

39 James S. Taylor, 'The unreformed workhouse, 1776-1834', in E. W. Martin ed., Comparative development in social welfare (London, 1972), 61-2; and BPP, 1777, IX, Report from the Committee appointed to inspect and consider the returns made by the Overseers of the Poor.

$40 \mathrm{Ibid}$. and see 1766 vestry minutes in DHC PE-BE/OV/1/2.

41 DHC PE-BE/OV/7/2.

42 BPP, 1818, XIX.1 (82), Abridgement of abstract of answers and returns relative to expense and maintenance of poor in England and Wales, 1813-1815, 104-5.

$43 \mathrm{DHC}$ PE-BE/OV/7/4-5. All results for the remainder of this section are based on these sources, unless otherwise noted.

44 See sections 7 and 8 for a discussion of these inmates.

45 King, Poverty and welfare, 161-2.

46 This was generally in the month of March, but occasionally the lists were made in February, April or May.

47 Charles H. Feinstein, 'Pessimism perpetuated: real wages and the standard of living in Britain during and after the industrial revolution', The Journal of Economic History 58, 3 (1998), 625-58; and W. A. Armstrong, 'Labour I: rural population growth, systems of employment and incomes', in G. E. Mingay ed., The agrarian history of England and Wales, Volume VI: 1750-1850 (Cambridge, 1989), 702-11.

48 Unfortunately there is a slight dip for 1814 as the source was heavily faded and partly illegible.

49 See note 13 for the literature on this topic.

50 See, for example, Mark Overton, Jane Whittle, Darron Dean and Andrew Hann, Production and consumption in English households, 1600-1750 (London, 2004); and Lorna Weatherill, Consumer behaviour and material culture in Britain 1660-1760, 2nd edn (London, 1996). 
51 King, 'Pauper inventories', 155-91; John Styles, 'Lodging at the Old Bailey: lodgings and their furnishings in eighteenth-century London', in John Styles and Amanda Vickery eds., Gender, taste, and material culture in Britain and North America 1700-1830 (New Haven, 2006), 61-80; and John Styles, The dress of the people: everyday fashion in eighteenth-century England (New Haven, 2007).

52 Craig Muldrew, Food, energy and the creation of industriousness: work and material culture in agrarian England, 1550-1780 (Cambridge, 2011), 101-2; and Ken Sneath, 'Consumption, wealth, indebtedness and social structure in early modern England' (unpublished Ph.D. thesis, University of Cambridge, 2008).

53 See, for example, Weatherill, Material culture, 191-4; and Sneath, 'Consumption', 102.

54 Adrian Green, 'Heartless and unhomely? Dwellings of the poor in East Anglia and north-east England', in McEwan and Sharpe, Accommodating, 69-101. Norfolk is one of the counties under study for my forthcoming thesis. My research has linked the inventories to wider sources and found that over one-third of the inventories that Green used were not pauper inventories and were instead made for reasons such as not paying debts, rent or poor rates.

55 Beverley Lemire, The business of everyday life: gender, practice and social politics in England, c.1600-1900 (Manchester, 2005), 7 and 82-109. Also see Tomkins, Urban poverty, 204-34 which discusses how the poor used credit and pawnshops.

56 Ann Kussmaul ed., The autobiography of Joseph Mayett of Quainton (1783-1839) (Chesham, 1986), 57, 59 and 65; and Mary Saxby, Memoirs of a female vagrant (London, 1806), 14-15, $25-8$ and $50-2$.

57 Laura Gowing, 'The twinkling of a bedstaff: recovering the social life of English beds 15001700', Home Cultures 11 (2014), 278-9.

58 Henry R. French, The middle sort of people in provincial England 1600-1750 (Oxford, 2007), $160-1$ and $189-96$.

59 Muldrew, Food, 1-162.

60 For other literature which has found contrary views to Muldrew, see Carole Shammas, The preindustrial consumer in England and America (Oxford, 1990), 121-56; and Roderick Floud, Robert W. Fogel, Bernard Harris and Sok Chul Hong, The changing body: health, nutrition, and human development in the western world since 1700 (Cambridge, 2011).

61 'Non-essential' items are loosely and broadly defined to include items that were not necessary to running a home and things that were probably only acquired when people had the means to or spare income. For further context, see Maxine Berg and Elizabeth Eger eds., Luxury in the eighteenth century: debates, desires and delectable goods (Basingstoke, 2003).

62 Lorna Weatherill, 'The meaning of consumer behaviour in late seventeenth- and early eighteenth-century England', in John Brewer and Roy Porter eds., Consumption and the world of goods (London, 1993), 215-17.

63 For more information on the poor's drinking of tea, see David Davies, The case of labourers in husbandry, Part I: A view to their distressed condition (London, 1795), 37-40.

64 The main exception to this is George Barnes who owned a large range of tea items. From DHC $\mathrm{PE}-\mathrm{TTG} / \mathrm{OV} / 1 / 1$.

65 In the context of Dorset and Beaminster more specifically, see French, Middle sort, 141-200, esp. 175-9.

66 See note 32.

67 Also see John Broad, 'Housing the rural poor in southern England, 1650-1850', The Agricultural History Review 48, 2 (2000), 151-70, here 159, which finds that even when a new workhouse was opened, many people still believed that families should live in their own homes.

68 Morrison, Workhouse, 3.

69 See 1766 vestry minutes in DHC PE-BE/OV/1/2. 
70 DHC PE-BE/OV/7/4-5.

71 Ottaway, Decline, 262.

72 Anonymous, An account of several work-houses, 88-9.

73 For example, Amanda Vickery, 'An Englishman's home is his castle? Thresholds, boundaries and privacies in the eighteenth-century London house', Past and Present 199 (2008), 147-73; David Hussey and Margaret Ponsonby, The single homemaker and material culture in the long eighteenth century (Farnham, 2012), 149-200; Ottaway, Decline, 247-76; Alannah Tomkins, 'Retirement from the noise and hurry of the world? The experience of almshouse life', in McEwan and Sharpe, Accommodating, 263-83; and Clive Edwards, Turning houses into homes: a history of the retailing and consumption of domestic furnishings (Aldershot, 2005).

74 Kent History and Library Centre (hereafter KHLC), Maidstone P308/12/1.

75 Cowe, Wimbledon, 59.

76 See 1785 workhouse rules in DHC PE-BE/OV/1/3.

77 See section 2.

78 DHC PE-BE/OV/7/10.

79 See 1818 vestry minutes in DHC PE-BE/OV/1/2 and DHC PE-BE/OV/7/1.

80 DHC PE-BE/OV/1/3-7.

81 Sidney Webb and Beatrice Webb, English local government: English poor law history: Part I. The old poor law (London, 1927), 221-40; and Crowther, Workhouse, 27-8.

82 Information and quote from DHC PE-BE/OV/7/10.

83 Anderson, 'Leeds', 98; and Peter Brears, 'Bastille soup and the skilly: workhouse food in Yorkshire', in C. Anne Wilson ed., Food for the community: special diets for special groups (Edinburgh, 1993), 130.

84 For example, see WAS D/P 17/17/14; and V. D. Harris, 'Poorhouses in England with special reference to Milford poorhouse and the relief of the poor in the parish', Milford-on-Sea Record Society 3 (1926), 26.

85 For example: Brears, 'Bastille', 116-50; and Alan Crosby, 'A poor diet for poor people? Workhouse food in Lancashire 1750-1834', Lancashire Local Historian 9 (1994), 20-7; Tomkins, Urban poverty, 50-65; and Muldrew, Food, 29-162.

86 Tomkins, Urban poverty, 50-65.

87 Overton, Whittle, Dean and Hann, Production, 100-1.

88 The dietary is found in DHC PE-BE/OV/1/3.

89 DHC PE-BE/OV/1/3-4 and DHC PE-BE/OV/3/1.

90 DHC PE-BE/OV/1/6-7, DHC PE-BE/OV/7/6, DHC PE-BE/OV/7/7-9 and PE-BE/OV/3/2-8.

$91 \mathrm{DHC} \mathrm{PE}-\mathrm{BE} / \mathrm{OV} / 7 / 3$, for instance, records the purchase of tea for the sick but not for other inmates.

92 See note 85 .

93 See section 1 for more information.

94 DHC PE-BE/OV/7/2.

95 See the 1818 vestry minutes in DHC PE-BE/OV/1/6. For more information on the gender- and age-related profile of inmates in Beaminster workhouse, see section 4.

96 Unfortunately, little can be said about Beaminster's hospital rooms. The rooms only contained beds and there are no other sources which reveal how the sick were treated.

97 All quotes from DHC PE-BE/SC/2/1. Admission information from DHC PE-BE/SC/1/1.

98 There was also a charity-funded school outside of the workhouse which could hold around 100 boys in 1814. Nevertheless, girls were excluded and due to the relatively large population of Beaminster, many other boys would have missed out. See DHC PE-BE/CH/1/1; and Eedle, $A$ history of Beaminster, 122-3.

99 See 1785 rules in DHC PE-BE/OV/1/3 and DHC PE-BE/OV/7/10.

100 See 1753 and 1786 vestry minutes in DHC PE-BE/OV/1/2-3. 
101 See 1753 and 1766 vestry minutes in DHC PE-BE/OV/1/2, 1774 vestry minutes and 1785 rules in DHC PE-BE/OV/1/3 and 1834 rules from DHC PE-BE/OV/7/10.

102 For example, see DHC PE-BE/OV/7/1, DHC PE-BE/OV/7/2 and DHC PE-BE/OV/7/6.

103 See 1766 vestry minutes in DHC PE-BE/OV/1/2.

104 See note 101.

105 DHC PE-BE/OV/7/10. Unfortunately, it is unclear if this was a new policy in 1834 or one that was applied from an earlier date.

106 DHC PE-BE/OV/7/3.

107 There is a healthy literature on the clothing of ordinary people and the parish poor which affords this claim. See the following authoritative book for an excellent opening to the subject: Styles, Dress.

108 Unless otherwise specified, the information for the rest of this article comes from DHC PE$\mathrm{BE} / \mathrm{OV} / 7 / 1$ and DHC PE-BE/OV/7/5 for workhouse storage inventories; DHC PE-BE/OV/7/ 4-5 for workhouse movements, names, ages and family structure; DHC PE-BE/OV/1/5-7 and DHC PE-BE/OV/1/8 for outdoor relief and parish work; DHC PE-BE/OV/9/1 and DHC PE$\mathrm{BE} / \mathrm{RE} / 3 / 1-2$ for information on earnings, occupation and children; and DHC PE-BE/RE/5/1 and DHC PE-BE/RE/4/2-4 for additional information on family structure, names and ages.

109 See note 13 for the literature on this subject.

110 Unfortunately, Elizabeth Paul from one of the inventories shares her name with another inmate so it has not been possible to reconstitute her background.

111 See section 2.

112 Jane Humphries, 'Household economy', in Roderick Floud and Paul Johnson eds., The Cambridge economic history of modern Britain, Volume 1: Industrialisation, 1700-1860 (Cambridge, 2008), 257-62. In the context of Beaminster, see DHC PE-BE/OV/9/1, which lists families' income by age and gender and clearly shows this trend.

113 Occasionally sources show this negotiation process. For instance, a vestry book from Lenham, Kent records the requests of paupers, and some paupers requested to leave the workhouse. Generally the wish was granted and the former inmate was also granted regular and/or casual outdoor relief. However, requests were refused if the parish thought that the inmate could not be generally self-sufficient. This suggests that parishes supported people in leaving the workhouse after temporary stays, as long as the subsequent help that they received from the parish was the smaller part of their earnings. KHLC P224/8/2.

114 Taylor, 'Unreformed', 62-3.

115 See note 28.

116 See section 5 for a discussion of the process of acquiring possessions during more prosperous times and then selling them when times were tough.

117 Mark Blaug, 'The poor law report reexamined', The Journal of Economic History 24, 2 (1964), 229-45, here 243; and Mark Blaug, 'The myth of the old poor law and the making of the new', Journal of Economic History 23, 2 (1963), 151-84, here 177. Also see Taylor, 'Unreformed', 57-84.

\section{FRENCH AND GERMAN ABSTRACTS}

Vie matérielle des pauvres et usage stratégique des ateliers paroissiaux (workhouses) qu'ils adoptent en Angleterre au cours des dernières décennies de l'ancienne Loi des pauvres

Cet article fait œuvre pionnière en étudiant trois différents types d'inventaires en Dorset afin de retracer la vie matérielle des pauvres qui vécurent au sein de l'atelier paroissial 
(workhouse) de Beaminster ou bien en dehors de l'établissement. L'auteur fait valoir que les indigents assistés qui vivaient à l'extérieur avaient une vie meilleure que ceux qui étaient pensionnaires de la workhouse et meilleure aussi en général que les pauvres avant qu'ils n'y entrassent. Il démontre que s'y faire admettre n'était pour les pauvres qu'un pis-aller dans le cadre de leur économie d'expédients. La documentation prouve que les pauvres valides utilisaient leur passage à la workhouse comme stratégie de survie à court terme, alors que les plus vulnérables avaient du mal à appliquer cette tactique. Ce travail améliore donc notre compréhension de la nature de l'assistance aux pauvres en Angleterre et contribue à donner plus de poids à des travaux historiques récents qui ont privilégié l'importance de l'action des pauvres eux-mêmes.

Materielles Leben der Armen und ihr strategischer Gebrauch des Arbeitshauses in den letzten Jahrzehnten des englischen 'Alten Armenrechts'

In diesem Beitrag werden erstmals drei unterschiedliche Typen von Inventaren aus Dorset miteinander verknüpft, um die materiellen Lebensbedingungen von Armenunterstützungsempfängern innerhalb und außerhalb des Arbeitshauses von Beaminster zu untersuchen. Die These ist, dass diejenigen, die Armenunterstützung außerhalb des Arbeitshauses bezogen, materiell besser dran waren als diejenigen, die bereits im Armenhaus einsaßen oder kurz vor der Einlieferung standen. Der Beitrag untersucht ferner, inwieweit die Armen die Unterbringung im Arbeitshaus als Teil ihrer Notbehelfsökonomie nutzten. Die Quellen zeigen, dass die arbeitsfähigen Armen das Arbeitshaus als kurzfristige Überlebensstrategie nutzten, während stärker verwundbare Insassen sich schwer taten, diese Taktik anzuwenden. Der Beitrag trägt daher zu einem besseren Verständnis des Wesens der Armenunterstützung bei und bekräftigt die jüngere historische Forschung in ihrer Auffassung, dass auch die Armen selbst eine gewisse Handlungsmacht besaßen. 